\title{
Applying PLEASE Strategy to Teach Writing Skill to Students with Different Linguistic Intelligences
}

\author{
Dyah Aminatun', Ngadiso ${ }^{2}$, Sri Marmanto ${ }^{3}$ \\ aminatun.dyah@gmail.com ${ }^{1}$,ngadiso@uns.ac.id ${ }^{2}$, srimarmanto@uns.ac.id ${ }^{3}$ \\ Universitas Teknokrat Indonesia ${ }^{1}$ \\ Universitas Sebelas Maret ${ }^{2,3}$
}

\begin{abstract}
PLEASE Strategy is a mnemonic that provides learners with a road map for writing a text. It is a strategy when a teacher teaches the students an acronym to remember each step in writing. PLEASE strategy will help students to write, to start the first sentence, and to put the data information in their writing. This article refers to an experimental study on the effectiveness of PLEASE Strategy to teach writing at the eleventh grade of SMA Negeri 1 Ngemplak. The samples were two classes, experimental class which was taught using PLEASE Strategy and control class which was taught using Guided Writing Strategy. To gain the data, two instruments were use, writing test and linguistic intelligence test. The data were, then, analyzed by using Multifactor Analysis of Variance ANOVA $2 \times 2$ and Tukey test. Before conducting the ANOVA test, pre-requisite test namely normality and homogeneity test were conducted. The findings of this research are: (1) PLEASE strategy is more effective than Guided Writing Strategy to teach writing; (2) The students having high linguistic intelligence have better writing skill than those having low linguistic intelligence; and (3) There is an interaction between teaching strategies and students' linguistic intelligence in teaching writing.
\end{abstract}

Key Words: experimental study, Guided Writing Strategy, linguistic intelligence, PLEASE Strategy, writing skill

\section{Introduction}

Writing is one of the language skills used for expressing the ideas, opinions, and the feelings in a form of written language. In this modern era, people use this skill almost every day through e-mail, short message service in phone, and chatting in social media. These examples are as proves that writing is an important skill to enable people to communicate with each other. Learning a language itself means learning to communicate with other people. English as a language internationally used by people around the world has a role to help people from different mother tongue communicate each other.

Indonesia in which English has a position as a foreign language demands its people to comprehend English as their first foreign language. It can be seen from the implementation of English teaching from the elementary until high education in Indonesia. From this fact, it cannot be denied that the position of English is really important for people nowadays. This importance relates to the ability of people in communicating in English. Therefore, teachers are also demanded to be able to teach both ways of communication in both oral and written.

Generally, people believe that speaking has an important role in communication. However, this paradigm needs to be shifted. People also need to know that speaking is not the only way to communicate. Writing also has a significant role in communication. It is in line with the Spartt (2005: 26) who says that writing is one of the four language skills that involves communicating a message (something to say) by making signs on a page. Writing cannot be left behind since it is a form of communication in which people are expected to understand our thought through reading our writing.

However, teaching writing to the students is not an easy thing. There are a lot of processes during the process of writing. Brown (2001: 336) states that writing is a thinking process in which a writer produces a final written product based on their thinking after the writer goes through the thinking process. Not only dealing with the ideas in mind, the writer also needs to deal with the components of writing such as grammatical structure, vocabulary, punctuation, and the mechanics of writing in order to make the written product can be absorbed clearly by the readers.

Moreover, Heaton (1975: 135) assumes that the writing skill is complex and sometimes difficult to teach, requiring mastery not only of grammatical and rhetorical devices but also of conceptual and judgmental element. This statement shows that writing is not only the production of the symbols; it is more than that. Therefore, an English teacher has an important role to help students develop their writing skill. 
Richards and Renandya (2002: 15) state that writing is a complex, recursive and creative process that is very similar in its general outlines for first and second language writers: learning to write requires the development of an efficient and effective composing process, writing is seen as involving a complex web or relation between writer, reader, and text. In addition, Ghaith (2002:1) explains that writing is a complex process that allows writers to explore thoughts and ideas, and make them visible and concrete.

However, students often make mistakes in composing their idea in a form of paragraph or text. Thus they find difficulties in delivering a message to the readers. There are lots of factors influencing students' writing ability. It could be external factors or internal factors both from the teacher's side and the students' side.

The external factor might come from the teacher's side. It can be in a form of teaching strategy used by teacher. In learning process, teacher tends to become a subject of learning and students are the object of learning. It means that the strategy used by teacher is teacher-centered. This thing will hinder students' skill to learn well. Applying a strategy which enables the students to start their writing and generate their idea will be the best way to teach writing. One of the strategies which can be used by the teacher in teaching writing is PLEASE strategy. Akincilar (2010: 53) utters that PLEASE strategy is effective for improving the students' ability in writing paragraph. The PLEASE Strategy is a mnemonic that provides learners with a road map for writing a paragraph. It is a strategy where teacher teaches the students the following acronym to remember each step in writing. As stated by Graham and Harris (2007), PLEASE reminds learners to carry out the following steps while writing.

$\mathrm{P}$ Pick a topic, an audience, and the appropriate textual format.

L List information about the topic to be used in sentence generation, ongoing evaluation, and organizational planning.

E Evaluate if the list is complete and plan how to organize the ideas that will be used to generate supporting sentences.

A Activate the paragraph with short and simple declarative topic sentence.

S Supply supporting sentences based on items from the list.

E End with a concluding sentence that rephrases the topic sentence, and evaluate the written work for errors in capitalization, punctuation, spelling, and appearance.

According to the steps above, it can be seen that PLEASE strategy will help students to write, to start the first sentence, to put the data information in their writing, and to end their writing. The strategy provides a structure to help students generate and organize ideas and to write sentences and paragraphs. The PLEASE strategy is useful because it provides cues to help students remember and apply activities involved in the process of planning and writing.

On the contrary, many teachers still use conventional strategy such as Guided Writing Strategy. This is an instructional based strategy which mainly teaches the writing process through modeling, supporting, and practicing. Dash and Dash (2007: 101) state that in guided composition, the students proceed with guidance from the teacher and in controlled direction. Choudhury (1998: 109-110) adds that in guided writing, teacher guides every sentence to be written. The teacher leads the students in their efforts. In the process of writing, the teacher should always provide additional guidance to the students. In conclusion, guided writing is a strategy of teaching writing in which teacher guides or helps students through stages of writing by modeling, providing the media, and preparing or supply the written materials which can be used to guide the students into independent writing.

In Guided Writing, the students are learning with the guidance from the teacher and in controlled direction. Because teacher has very significant role in the process of teaching and learning in the classroom, students are really dependent to the teacher. Thus, it takes a long time to make them produce a text by themselves without any help from the teacher. The strategy used by teacher also cannot grab students' attention and interest towards writing. Most of students do not show their enthusiasm and just keep in silent. In this case, teacher needs to be creative in creating learning ambiance and using appropriate strategy which leads students to be more interested, active and independence in writing. Therefore, students will be able to increase their competency to write well, as well as to implement the correct writing components.

The internal factors which influence student's performance in writing can be in a form of psychological aspects such as students' interest, motivation, learning style, and even students' verbal intelligence. Verbal intelligence or also known as linguistic intelligence is supposed to be one of the factors which influences students' writing skill. Gardner (1983: 77) which conveys that linguistic intelligence is one of the multiple intelligences which involves sensitivity to spoken and written language, the ability to learn language and the capacity to use language to accomplish certain goals. Therefore, linguistic intelligence really matters in influencing students' writing skill. 
Gardner (Amstrong, 2009: 6) explains that a person with linguistic intelligence has the capacity to use words effectively, whether oral (e.g., as a storyteller, orator, or politician) or writing (e.g., as a poet, playwright, editor, or journalist). Verbal/linguistic intelligence and the capacity to use words to communicate is a skill that comes from the temporal cortex on the left side of the brain, names Broca's Area (Edu-Nova, 2012). It has four areas of sensitivity namely, semantics, phonology, syntax, and praxis. The combination of these sensitivities impacts an individual's ability to speak, write, and understand words. Linguistic intelligence - also known as verbal-linguistic - is one of the many types of intelligence described in multiple intelligences theory. People with significant linguistic intelligence are often good at languages and enjoy reading and writing (British Council, 2011). From those explanation, it can be summarized that verbal-linguistic intelligence or is called as linguistic intelligence is the ability to think in words and to use language to express and appreciate complex meanings.

To infer the explanation of previously discussed, the researcher formulates the hypotheses as follows: (1) PLEASE is more effective than Guided Writing in teaching writing to the eleventh grade students of SMA Negeri 1 Ngemplak in the academic year of 2015/2016; (2) Student with high level of linguistic intelligence have better writing skills than those with low level of linguistic intelligence; and (3) There is an interaction between teaching strategies and students' linguistic intelligence in teaching writing to the eleventh grade students of SMA Negeri 1 Ngemplak in the academic year of 2015/2016.

\section{Research Method}

This research was conducted at the eleventh grade of SMA Negeri 1 Ngemplak, Boyolali, Central Java. This research was conducted from July 2015 until April 2016. The research method used in this research is experimental research. The researcher used quasi-experimental design because the sample was taken from two classes that already exist at that school. The design of this research was a simple factorial design $2 \times 2$ with Post-Test Only Design. There were two groups in the research, the experimental group was taught by using PLEASE strategy, while the control group was taught by using Guided Writing. At the end of treatment, a post test is given in the form of writing test. The result was analyzed by comparing the post-test scores of both groups by using ANOVA or F-test and then by using Tukey test.

The population of this research was all the eleventh grade students of SMA Negeri 1 Ngemplak in the academic year of 2015/2016. The researcher used cluster-random sampling to and took two classes from nine classes to be the sample of this research. Each class consists of 28 students. The first class was experimental class taught by using PLEASE, and another was control class taught by using Guided Writing.

The researcher used two instruments of collecting data in this research, writing test and linguistic intelligence test. These two tests was assessed by using readability of the test instruction which informs whether the test instructions are appropriately readable for students and whether the instruction of writing and linguistic intelligence test can be understood by the students. Besides that, the instrument of linguistic intelligence test should be valid and reliable. From the result of validity and reliability test, the researcher took 30 valid questions to be the instrument of the linguistic intelligence test and the instrument was reliable since the value of $r=0.702$.

The techniques used in analyzing the data were descriptive analysis and inferential analysis. Descriptive analysis was used to know the mean, median, mode and standard deviation of the scores of the writing test. Inferential analysis used was multifactor analysis of variance $2 \times 2$. It was used to test the hypotheses. $\mathrm{H}_{\mathrm{o}}$ is rejected if $\mathrm{F}_{\mathrm{o}}$ is higher than $\mathrm{F}_{\mathrm{t}}$. If $\mathrm{H}_{\mathrm{o}}$ is rejected, the analysis was continued to know which group is better by using Tukey test.

\section{Findings and Discussion}

To test the hypothesis of this research, the researcher was using Multifactor Analysis of Variance (ANOVA) $2 \times 2$. Before ANOVA and Tukey test were two kinds of test. Those are normality test and homogeneity test. The result of the tests was used as the requirement before ANOVA test and Tukey test.

There are eight groups: (1) The data of the writing test of the students who are taught by using PLEASE $\left(A_{1}\right)$; (2) The data of the writing test of the students who are taught by using Guided Writing $\left(A_{2}\right)$; (3) The data of the writing test of the students having high linguistic intelligence $\left(B_{1}\right)$; (4) The data of the writing test of the students having low linguistic intelligence $\left(\mathrm{B}_{2}\right)$; (5) The data of the writing test of the students having high linguistic intelligence who are taught by using PLEASE $\left(\mathrm{A}_{1} \mathrm{~B}_{1}\right) ;(6)$ The data of the writing test of the students having low linguistic intelligence who are taught by using PLEASE $\left(\mathrm{A}_{1} \mathrm{~B}_{2}\right)$; (7) The data of the writing test of the students 
having high linguistic intelligence who are taught by using Guided Writing $\left(\mathrm{A}_{2} \mathrm{~B}_{1}\right)$; and $(8)$ The data of the writing test of the students having low linguistic intelligence who are taught by using Guided Writing $\left(\mathrm{A}_{2} \mathrm{~B}_{2}\right)$.

The data can be said as normal data if $\mathrm{L}_{\mathrm{o}}$ ( $\mathrm{L}_{\mathrm{obtained}}$ ) is lower than $\mathrm{L}_{\mathrm{t}}\left(\mathrm{L}_{\mathrm{table}}\right)$ at the level of significance $\alpha=$ 0.05. From the result of normality test of all eight groups, it can be concluded that all the data of writing scores for the eight groups are in normal distribution because $\mathrm{L}_{\mathrm{o}}$ of the entire data are lower than $\mathrm{L}_{\mathrm{t}}\left(\mathrm{L}_{\mathrm{o}}<\mathrm{L}_{\mathrm{t}}\right)$ at the level of significance $\alpha=0.05$.

The result of homogeneity test is 6.06. The data are homogeneous if $\chi_{0}^{2}\left(\chi_{\text {obtained }}\right)$ is lower than $\chi_{t}^{2}\left(\chi_{\text {table }}\right)$ at the level of significance $\alpha=0.05$. Because $\chi_{0}^{2}(6.06)$ is lower than $\chi_{t}^{2}(7.81)$, it can be said that the data are homogeneous. It means that the data of this research are obtained from homogeneous sample.

After the data are normal and homogeneous, then the data are analyzed by using Multifactor Analysis of Variance (ANOVA) 2x2. This test is used to know the effects of the independent variables and attributive variable toward the dependent variable. In addition, it functions to check if there is an interaction among those variables. The hypothesis is rejected if $\mathrm{F}_{\mathrm{o}}$ is higher than $\mathrm{F}_{\mathrm{t}}\left(\mathrm{F}_{\mathrm{o}}>\mathrm{F}_{\mathrm{t}}\right)$. The mean scores and summary of the data is presented in table 1 and 2.

Table 1. The mean scores

\begin{tabular}{|c|c|c|c|c|c|}
\hline \multirow{2}{*}{$\begin{array}{c}\text { Linguistic } \\
\text { Intelligence (B) }\end{array}$} & \multicolumn{3}{|c|}{ Teaching Strategies } & & \multirow[b]{2}{*}{ Total } \\
\hline & $\begin{array}{c}\text { PLEASE Strategy } \\
\left(\mathrm{A}_{1}\right)\end{array}$ & & $\begin{array}{c}\text { Guided Writing } \\
\text { Strategy }\left(\mathbf{A}_{2}\right)\end{array}$ & & \\
\hline $\begin{array}{l}\text { High Linguistic } \\
\text { Intelligence }\left(\mathbf{B}_{1}\right)\end{array}$ & 77.21 & & 65.36 & & 71.29 \\
\hline $\begin{array}{l}\text { Low Linguistic } \\
\text { Intelligence }\left(\mathbf{B}_{2}\right)\end{array}$ & 66.07 & & 69.57 & & 67.82 \\
\hline Total & 71.64 & & 67.46 & & 69.55 \\
\hline Source of Variance & SS & df & MS & $\mathbf{F}_{\mathbf{0}}$ & $F_{\mathbf{t}(0.05)}$ \\
\hline $\begin{array}{l}\text { Between columns } \\
\text { (Teaching Strategies) }\end{array}$ & 244.45 & 1 & 244.45 & 7.102 & 4.00 \\
\hline Between rows (LI) & 168.02 & 1 & 168.02 & 4.881 & \\
\hline $\begin{array}{l}\text { Columns by rows } \\
\text { (interaction) }\end{array}$ & 825.44 & 1 & 825.44 & 23.986 & \\
\hline Between groups & 1237.91 & 3 & 412.64 & & \\
\hline Within group & 1789.93 & 52 & 34.42 & & \\
\hline Total & 4265.75 & 55 & & & \\
\hline
\end{tabular}

a. Because $F_{o}$ between columns (7.102) is higher than $F_{t}$ at the level of significance $\alpha=0.05(4.00)$, $H_{o}$ is rejected and there is significant difference between PLEASE Strategy and Guided Writing Strategy to teach writing. Because the mean score of $A_{1}$ (71.64) is higher than that of $A_{2}$ (67.46), it can be concluded that PLEASE Strategy is more effective than Guided Writing Strategy to teach writing.

b. Because $F_{o}$ between rows (4.881) is higher than $F_{t}$ at the level of significance $\alpha=0.05(4.00), H_{o}$ is rejected and there is significant difference in writing skill between the students who have high and low linguistic intelligence. Because the mean scores of $B_{1}$ (71.29) is higher than the mean scores of $B_{2}$ (67.82), it can be concluded that the students who have high linguistic intelligence have better writing skill than those having low linguistic intelligence.

c. Because $F_{o}$ columns by rows (23.986) is higher than $F_{t}$ at the level of significance $\alpha=0.05(4.00)$, $H_{o}$ is rejected and there is an interaction between teaching strategies and students' linguistic intelligence to teach writing. Thus, it can be concluded that the effectiveness of teaching strategies is influenced by the level of students' linguistic intelligence.

After knowing the effects and the interaction of independent variables toward the dependent variable, it is also necessary to compare the mean of every treatment with the other means using Tukey test. This test is used to identify which means are significantly different from the other. The data summaryr is presented in table 3 . 
Table 3. The summary of Tukey test

\begin{tabular}{cccccccc}
\hline No & Data & Sample & $\mathbf{q}_{\mathbf{o}}$ & $\mathbf{q t}_{\mathbf{t}}$ & $\boldsymbol{\alpha}$ & Meaning & Status \\
\hline 1 & $\mathrm{~A}_{1}$ and $\mathrm{A}_{2}$ & 28 & 3.77 & 2.89 & 0.05 & $\mathrm{q}_{\mathrm{o}}>\mathrm{q}_{\mathrm{t}}$ & Significant \\
2 & $\mathrm{~B}_{1}$ and $\mathrm{B}_{2}$ & 28 & 3.13 & 2.89 & 0.05 & $\mathrm{q}_{\mathrm{o}}>\mathrm{q}_{\mathrm{t}}$ & Significant \\
3 & $\mathrm{~A}_{1} \mathrm{~B}_{1}$ and $\mathrm{A}_{2} \mathrm{~B}_{1}$ & 14 & 7.39 & 3.03 & 0.05 & $\mathrm{q}_{\mathrm{o}}>\mathrm{q}_{\mathrm{t}}$ & Significant \\
4 & $\mathrm{~A}_{1} \mathrm{~B}_{2}$ and $\mathrm{A}_{2} \mathrm{~B}_{2}$ & 14 & 2.23 & 3.03 & 0.05 & $\mathrm{q}_{\mathrm{o}}<\mathrm{q}_{\mathrm{t}}$ & Not Significant \\
\hline
\end{tabular}

a. Because the mean of $A_{1}$ (71.64) is higher than that of $A_{2}$ (67.46), it can be concluded that PLEASE Strategy is more effective than Guided Writing Strategy to teach writing.

b. Because the mean scores of $B_{1}$ (71.29) is higher than the mean scores of $B_{2}(67.82)$, it can be concluded that the students having high creativity have better writing skill than those having low creativity.

c. Because the mean of $A_{1} B_{1}$ (77.21) is higher than that of $A_{2} B_{1}$ (65.36), it can be concluded that PLEASE Strategy is more effective than Guided Writing Strategy to teach writing for students having high linguistic intelligence.

d. The result that it is not significant, so it means that PLEASE Strategy is as effective as Guided Writing Strategy to teach writing for students having low linguistic intelligence.

The findings of this research reveal that there is a significant difference between teaching writing by using PLEASE Strategy and teaching writing by using Guided Writing. PLEASE Strategy is more effective than Guided Writing Strategy to teach writing seen from the mean scores of the students.

PLEASE is a strategy which can help students to learn writing well. This strategy is useful because it provides cues to help students remember and apply activities involved in the process of planning and writing. The steps of PLEASE Strategy help the students to write, to start the first sentence, to put data information in their writing, and to end writing. Akincilar (2010: 53) also utters that PLEASE strategy is effective for improving the students' ability in writing paragraph. Besides that, PLEASE is a student-centered strategy because the students are free and independent in developing the ideas through steps of PLEASE which have been memorized by them. The last, PLEASE also gives a chance to the students to do peer correction, so students will be able to do reflection to the work which they have already made.

On the other hand, Guided Writing is a process of writing in which the teacher guides and helps the students either through oral or written assistance. During the writing process, teacher has a big role to provide students with the guidance and instructions. The teacher applies numerous ways to guide the students by prompting, explaining, giving important point, eliciting the points from other pupils, writing the point on the board, and other ways. Chondhury (1998: 109-110) who states that in guided writing, teacher guides every sentence to be written. Teacher leads the students in their efforts. In the process of writing, the teacher should always provide additional guidance to the students. Consequently, the students' creativity in developing their ideas is less emphasized during the process of writing. It will make the students more dependent to the teacher and tend to be passive learners.

This research also shows that there is an interaction effect between teaching strategy and students' linguistic intelligence on students' writing skill. The data show that PLEASE Strategy is significantly difference from Guided Writing to teach writing for the student who have high linguistic intelligence, but the difference happens insignificantly to those who have low linguistic intelligence.

PLEASE Strategy is an effective strategy to teach writing for the students having high linguistic intelligence because this strategy includes mnemonic strategy which is really suitable with the characteristic of high linguistic students in learning. As stated by Gardner in Amstrong (2009: 6), linguistic intelligence has several aspects such as, mnemonic which is the ability to use language to remember information. Students having high linguistic intelligence will be faster to memorize steps and learn new materials given by the teacher by using such a mnemonic device. In this case, PLEASE Strategy is an understandable and practicable strategy which will help students to easily understand the materials of writing. PLEASE Strategy supports the use of mnemonic device which will help students remember a new thing, in this case is the step of writing. Therefore, the implementation of PLEASE in teaching writing is appropriate for students who have high linguistic intelligence.

Students having low linguistic intelligence have contradictive characteristics with the high one. They are characterized by no initiation during language learning, no enthusiasm with information, and no fascination to express their ideas through words. Further, in the process of learning writing, students with low level of linguistic intelligence will be less enthusiastic to take a part in activities. They cannot give new ideas and share with others since the information they have is limited. They show no interest during the process of writing by rely on what the teacher asks and what their friends do. They are unable to come up with their idea and opinion in their mind to be conveyed into a clear and understandable language. 
Because of the characteristics of students who have low linguistic intelligence, PLEASE Strategy and Guided Writing Strategy can be used to teach writing. It occurs because some characteristics of students having low linguistic intelligence hinder them to show their skill to produce a good writing. Raushuluddin (2015) implies that children who have low linguistic intelligence are not interested in words and do not like to play with words; they do not like reading, writing, and have difficulty to absorb new information. From those characteristics, it can be inferred that students with low linguistic intelligence need a lot of efforts and have difficulty to learn language since language is strongly related to words no matter the strategy is. Therefore, PLEASE Strategy is as effective as Guided Writing Strategy to teach writing for students having low level of linguistic intelligence.

\section{Conclusion and Suggestions}

There are some research findings that can be taken: (1) PLEASE Strategy is more effective than Guided Writing Strategy to teach writing; (2) The students having high linguistic intelligence have better writing skill than those having low linguistic intelligence; and (3) There is an interaction between teaching strategies and students' linguistic intelligence in teaching writing. In this case, students having high linguistic intelligence have better writing skill than those having low linguistic intelligence when they are taught using PLEASE Strategy. However, students having low linguistic intelligence have better writing skill when they are taught using Guided Writing Strategy.

From the research findings, it can be suggested that: (1) It is better to adopt or apply PLEASE in teaching writing; (2) Students may improve their writing skill through PLEASE Strategy with or without the existence of the teacher. This will lead students to become autonomous learners. It is also suggested that students use this strategy when they are writing any kinds of text, such as articles, papers, or stories for pleasure; and (3) it is better to use the findings of this research as a literature reference for other researcher with different variables or different population characteristics.

\section{References}

Akincilar, V. 2010. The Effect of PLEASE Strategy Training Through The Self-Regulated Strategy Development (SRSD) Model on Fifth Grade EFL Students' Descriptive Writing: Strategy Training on Planning. Middle East Technical University. Retrieved from http://etd.lib.metu.edu.tr/upload/3/12611947/ index.pdf.

Amstrong, T. 2009. Multiple Intelligences in the Classroom. Alexandria: ASCD.

Brown, H. D. 2001. Teaching by Principles: An Interactive Approach to Language Pedagogy, $2^{\text {nd }}$ Edition. New York: Longman.

Choudhury, N. R. 1998. Teaching English in Indian Schools. New Delhi: APH Publishing Corporation.

Cresswell, J. W. 2008. Educational Research: Planning, Conducting, and Evaluating Quantitative, and Qualitative Research. New Jersey: Pearson Education, Inc.

Dash, Neena \& Dash. 2007. Teaching English as an Additional Language. New Delhi: Atlantic Publishers \& Distributors, Ltd.

Davis, K., Christodoulou, J., Seider, S., Gardner, H. The Theory of Multiple Intelligences. Harvard University.

Gardner, H. 1983. Frames of Minds: The Theory of Multiple Intelligence, $10^{\text {th }}$ Ed. New York: Basic Books.

Graham, S., \& Harris, K. R. 2007. Best Practices in Teaching Planning. In Graham, S., Macarthur, A., \& Fitzgerald, J (Eds.), Best Practices in Writing Instruction. 119-140. New York, NY: The Guilford Press.

Harmer, J. 2001. How to Teach English: An Introduction to the Practice of English Language Teaching. Longman: London.

Heaton, B. J. 1975. Writing English Language Test. Longman: London and New York.

Hoerr, T. 2000. Becoming a Multiple Intelligences School. Alexandria: ASCD.

Liza, M., \& Rafnaldi. 2013. Using PLEASE strategy in teaching writing a descriptive text. Journal of English Language Teaching, 1(2), 436-444. 
Raushuluddin 2015. Mengetahui Kecerdasan Linguistik Anak. Retrieved from http://raushuluddin.blogspot.co.id/2015/12/10-pertanyaan-untuk-mengetahui.html

Richards, J. C. \& Renandya, W. A. 2002. Methodology in Language Teaching: An Anthology of Current Practice. Cambridge: Cambridge University Press.

Spartt, Mary \& Alan. 2005. The Teaching Knowledge Test Course (TKT). New York: Cambridge University Press.

The David Lazear. 2003. A Different Kind of Smart, A Different Kind of Learning. Multiple Intelligences. Retrieved form http://davidlazeargroup.com

Welch, M. 1992. The "PLEASE" Strategy: A Metacognitive Learning Strategy for Improving the Paragraph Writing of Students with Mild Learning Disabilities. Learning Disability Quarterly, 15, (2), 119-128.

Wilson, L. O. 2014. Multiple Intelligence Indicators. The Second Principle. Retrieved from http://thesecondprinciple.com/optimal-learning/multiple-intelligence-indicators/ 